\title{
Implementasi Pembelajaran Tematik Berbasis Sistem dalam Jaringan di Kelas II Sekolah Dasar Negeri Karangmangu 02
}

\author{
Sairah \\ SD Negeri Karangmangu 02 \\ iratata098@gmail.com
}

\section{Article History}

received 3/12/2020

revised $17 / 12 / 2020$

accepted 31/12/2020

\begin{abstract}
This research aims to describe implementation of system-based thematic learning, in terms of supporting and inhibiting factors, efforts to optimize supporting factors, and overcoming inhibiting factors. This research was conducted at thrid grade SDN Karangmangu 02 Kab Tegal. This research used descriptive qualitative methods. The subjects of this research were teachers, students, and parents. Data collection techniques were observation, interviews, and document study. Implementation of online system-based thematic learning to regard condition of students and parents considerations. In implementation there are supporting factors are interest in learning, maximum parental assistance, availability of mobile phones, internet quota, and a stable network. While the inhibiting factors are lazy to learn, less maximal parental assistance, limited cellphone facilities, internet quota limited, and unstable network. Efforts to optimize the supporting factors are motivation and data collection on the distribution of internet quota assistance on a regular basis. Efforts to overcome inhibiting factors are teacher motivation and assistance, between parents and students, as well as the role of the community. This research is important for improve learning during the Covid-19 pandemic.
\end{abstract}

Keywords: thematic learning, online learning system, elementary school

\begin{abstract}
Abstrak
Penelitian ini bertujuan untuk mendeskripsikan pelaksanaan pembelajaran tematik berbasis sistem, ditinjau dari faktor pendukung dan penghambat, upaya mengoptimalkan faktor pendukung, dan mengatasi faktor penghambat. Penelitian ini dilaksanakan di kelas II SDN Karangmangu 02 Tarub Kab. Tegal. Penelitian ini menggunakan metode deskriptif kualitatif. Subjek penelitian ini adalah guru, siswa, dan orang tua. Teknik pengumpulan data adalah observasi, wawancara, dan studi dokumen. Pelaksanaan pembelajaran tematik berbasis sistem online dengan memperhatikan kondisi siswa dan pertimbangan orang tua. Dalam pelaksanaannya terdapat faktor pendukung yaitu minat belajar, pendampingan orang tua yang maksimal, ketersediaan handphone, kuota internet, dan jaringan yang stabil. Sedangkan faktor penghambatnya adalah malas belajar, pendampingan orang tua yang kurang maksimal, fasilitas handphone yang terbatas, kuota internet yang terbatas, dan jaringan yang tidak stabil. Upaya optimalisasi faktor pendukung tersebut adalah motivasi dan pendataan penyaluran bantuan kuota internet secara berkala. Upaya mengatasi faktor penghambat adalah motivasi dan pendampingan guru, antara orang tua dan siswa, serta peran masyarakat. Penelitian ini penting untuk meningkatkan pembelajaran selama pandemi Covid-19.
\end{abstract}

Kata kunci: pembelajaran tematik sistem pembelajaran online sekolah dasar

Social, Humanities, and Education Studies (SHEs): Conference Series https://jurnal.uns.ac.id/shes

p-ISSN 2620-9284

e-ISSN 2620-9292 


\section{PENDAHULUAN}

Pandemi Covid 2019 telah mengimbas dunia pendidikan. Kebijakan- kebijakan baik dari Pemerintah Pusat maupun daerah dibuat. Peraturan Pemerintah Nomor 21 Tahun 2020 tentang Pembatasan Sosial Berskala Besar. Pemberlakuan kebijakan karantina wilayah dan PSBB berdampak pada aktivitas bidang termasuk pendidikan. Kemendikbud mengambil kebijakan dalam Surat Edaran Nomor 15 Tahun 2020 tentang Pedoman Penyelenggaraan Belajar Dari Rumah Dalam Masa Darurat Penyebaran Covid-19 . Menurut surat edaran dari Kemendikbud, Banyak jenjang pendidikan yang menggunakan jaringan dalam pembelajaran. Pembelajaran daring artinya adalah pembelajaran yang dilakukan secara online, menggunakan aplikasi pembelajaran maupun jejaring sosial. Pembelajaran daring merupakan pembelajaran yang dilakukan tanpa melakukan tatap muka, tetapi melalui platform yang telah tersedia. Sebelum pandemi Covid 10 pembelajaran dilakukan secara offline yaitu siswa dan guru bertatap muka dalam proses pembelajaran, namun setelah adanya pandemi Covid 19 pembelajaran beralih kedalam pembelajaran online. Banyak aplikasi yang digunakan dalam pembelajaran online, diantaranya lewat aplikasi WA, GOOGLE CLASROOM, GOOGLE MEET, dan masih manyak lainnya yang dilakukan oleh guru dalam pembelajaran. Guru harus memiliki kompetensi yang baik dalam IT dalam pembelajaran online. Bagaimana siswa dapat mampu pembelajaran online sedangkan guru belum sepenuhnya menguasai IT.

Banyak kebijakan yang dikeluarkan oleh Pemerintah dalam pembelajaran online. Salah satu diantaranya adalah dibagikannya kuota gratis untuk guru dan siswa. Pembelajaran tematik adalah suatu model pembelajaran yang memadukan beberapa materi pembelajaran dari berbagai standar kompetensi dan kompetensi dasar dari satu atau beberapa mata pelajaran . Pengertian pembelajaran tematik yaitu model terapan pembelajaran terpadu saling terintegrasi dalam beberapa mata pelajaran yang terikat oleh tema . dulu pembelajaran dilakukan di kelas dengan bertatap muka, sekarang pembelajaran ke dunia maya. Kurangnya penguasaan IT menjadi faktor utama hambatan tersenderi bagi guru, siswa dan orangtua. Ditinjau dari pelaksanaan, pembelajaran secara tatap muka, guru mendampingi secara langsung masih ditemukan peserta didik yang kurang fokus belajar tatap muka dalam pembelajaran anak bisa lebih fokus daripada pembelajaran dunia maya, apalagi faktor jaringan atau sinyal juga berpengaruh. Orangtua dalam pembelajaran online lebih berperan aktif untuk mengawasi pembelajaran anaknya. Tidak dapat dipungkiri, orangtua sibuk dengan aktivitasnya sendiri. Hasil pekerjaan siswa kadang tidak dikumpulkan pada saat itu juga namun dikumpulkan malam hari setelah orangtua berada di rumah dan kadang juga yang mengerjakan adalah orangtua. Kita sebagai guru tidak mungkin menerangkan pembelajaran lewat aplikasi, kaena sulit bagi siswa SD menggunakan aplikasi, paling aplikasi yang bisa digunakan adalah WA. Kita sebagai guru hanya bisa mengshare materi pembelajaran. Guru mengirimkan materi dan tugas lewat WA dan mereka para siswa mengumpulkannya dengan mendatangi ke SD meskipun dilakukan tiga kali pertemuan dalam seminggu, karena para guru ada di sekolah. Penelitian tentang pembelajaran dalam jaringan pernah diteliti oleh Hilna Putria (2020) yang membuktikan bahwa pembelajaran dalam jaringan kurang efektif untuk guru terutama usia sekolah dasar. Adanya faktor penghambat tentang fasilitas handphone dan orang tua yang sibuk bekerja. Berdasarkan penelitian yang dilakukan Henry Aditia Rigianti (2020) menyatakan bahwa kendala yang dialami guru selama pembelajaran daring yaitu aplikasi pembelajaran, jaringan internet dan gawai, pengelolaan pembelajaran, penilaian, dan pengawasan. Permasalahan pembelajaran dalam jaringan tidak hanya dirasakan oleh guru tetapi juga peserta didik dan orang tua yang membutuhkan solusi untuk mengatasinya. Berdasarkan permasalahan tersebut, maka peneliti tertarik untuk mengkaji berbagai kemungkinan masalah yang dapat timbul dalam implementasi pembelajaran tematik berbasis sistem dalam jaringan di kelas II SDN Karangmangu 02 
pada tahun 2020. Tujuan penelitian ini adalah mendeskripsikan pembelajaran tematik berbasis sistem dalam jaringan, mengidentifikasi faktor pendukung dan faktor penghambat, serta mendeskripsikan upaya mengoptimalkan faktor pendukung dan upaya mengatasi faktor penghambat. Manfaat penelitian ini adalah memberikan masukan untuk meninjau pelaksanaan pembelajaran tematik berbasis sistem dalam jaringan di sekolah dasar.

\section{METODE}

Bagian ini disajikan jika artikel merupakan hasil penelitian (hasil kajian tidak perlu Penelitian ini menggunakan metode deksriptif kualitatif. metode analisis deskriptif kualitatif adalah menganalisis, menggambarkan, dan meringkas berbagai kondisi, situasi dari berbagai data yang dikumpulkan berupa hasil wawacara atau pengamatan mengnai masalah yang diteliti yang terjadi di lapangan. Penelitian ini dilaksanakan di kelas II SD Negeri Karangmangu 02. Pendekatan penelitian ini menggunakan studi kasus. Jenis pendekatan studi kasus ini merupakan jenis pendekatan yang digunakan untuk menyelidiki dan memahami sebuah kejadian atau masalah yang telah terjadi dengan mengumpulkan berbagai macam informasi yang kemudian diolah untuk mendapatkan sebuah solusi agar masalah yang diungkap dapat terselesaikan.. Subjek penelitian ini adalah guru, peserta didik, dan orang tua. Teknik pengambilan sampel menggunakan purposive sampling yaitu suatu teknik pengambilan sampel yang menggunakan pertimbangan tertentu .Teknik pengumpulan data menggunakan observasi, wawancara, dan studi dokumen. Teknik uji validitas data menggunakan triangulasi teknik dan triangulasi sumber. Menurut Miles dan Huberman teknik analisis data menggunakan pengumpulan data, redukasi data, penyajian data, dan penarikan kesimpulan. Prosedur penelitian melalui beberapa tahap yaitu pemilihan tema, penyusunan rumusan masalah, pemilihan subjek penelitian, penyusunan instrument penelitian, pengumpulan data analisis data, validitas data, dan penyusunan laporan penelitian.

\section{HASIL DAN PEMBAHASAN}

tBerdasarkan hasil temuan, implementasi pembelajaran tematik berbasis sistem dalam jaringan Tema 8 Keselamatan di rumah dan diperjalanan. Pelaksanaan pembelajaran tematik berbasis sistem dalam jaringan Tema 8 Keselamatan di rumah dan diperjalanan dapat terlaksana dengan baik yang ditunjukkan dengan hasil belajar peserta didik diatas nilai batas KKM yaitu 60 .

Tahapan pembelajaran tematik berbasis sistem dalam jaringan yaitu :

ahap perencanaan pembelajaran tematik berbasis sistem dalam jaringan berupa guru memastikan kompetensi pembelajaran yang dicapai sesuai dengan silabus dan menyiapkan RPP, menyiapkan materi dari buku paket tematik dan buku pendamping belajar LKS, menentukan metode yaitu penugasan dan tanya jawab dengan menggunakan interaksi melalui whatsApp grup kelas, dan menentukan jenis media yaitu video, rekaman, dan gambar foto. Perencanaan pembelajaran adalah gambaran umum tentang langkah-langkah yang akan dilakukan guru untuk mencapai tujuan yang ditetapkan secara efektif dan efisien

b. Tahap Pelaksanaan pembelajaran berupa kegiatan pendahuluan, kegiatan inti, dan kegiatan penutup. Kegiatan pendahuluan dilakukan dengan memberikan salam, menanyakan kabar, dan presensi, serta pemberian motivasi. Kegiatan inti dilakukan dengan pengiriman foto materi dari buku tematik dan LKS dengan pemberian keterangan tanggal, tema, subtema, pembelajaran, dan halaman. Guru menjelaskan materi dengan bantuan media video, rekaman, dan gambar foto, diberikan penugasan, dan sesi tanya jawab. Kegiatan penutup dilakukan dengan guru memberikan tindak lanjut agar peserta didik tetap mengerjakan LKS sebagai latihan soal dan pembelajaran ditutup dengan salam penutup. 
Tahap evaluasi dilakukan dengan penilaian autentik yaitu pengetahuan, afektif, dan keterampilan. Penilaian pengetahuan dari tugas dan ulangan harian, penilaian afektif dari ketepatan pengumpulan tugas, dan penilaian keterampilan dari praktik. Sesuai dengan pengertian evaluasi adalah suatu proses yang sistematis dan berkelanjutan sebagai langkah menentukan kualitas (nilai dan arti), dengan melakukan pertimbangan dan kriteria tertentu untuk pengambilan keputusan .Evaluasi dilakukan secara sistematis dan berkelanjutan agar mendapatkan gambaran kemampuan peserta didik .

Pembelajaran tematik berbasis sistem dalam jaringan merupakan kebijakan baru. Sistem pembelajaran dalam jaringan memiliki tantangan untuk guru, peserta didik, dan orang tua

Dalam pelaksanaanya memiliki faktor pendukung dan penghambat yang berasal dari internal maupun eksternal.

Tabel 1. Faktor Pendukung dan Faktor Penghambat

\begin{tabular}{lll}
\hline & Faktor Pendukung & \multicolumn{1}{c}{ Penghambat } \\
\hline Internal & Motivasi belajar & Kurangnya rasa ingin tahu \\
Eksternal & $\begin{array}{l}\text { Adanya pendampingan } \\
\text { orangtua }\end{array}$ & $\begin{array}{l}\text { Orangtua mendampingi hanya di } \\
\text { malam hari }\end{array}$
\end{tabular}

Adanya perangkat gadged Belum tersedianya gadged

Siswa banyak yang

sudah hafal

menggunakan

aplikasi WA

Adanya bantuan kuota internet dari

pemerintah

Jaringan internet

stabil
Aplikasi WA yang menggunakan adalah orangtua karena HP dipegangorangtua

Bantuan kuota tidak setiap bulan ada

Jaringan internet kurang stabil

Tabel tersebut menunjukkan bahwa faktor pendukung dan penghambat dalam pembelajaran online. Minat belajar adalah rasa menyukai atau ketertarikan tentang sesuatu dan tidak ada yang menyuruh untuk belajar . aplikasi WA yang kurang menarik menyebabkan anak cepat bosan. Orangtua disini sangat berpengaruh dalam pembelajaran orangtualah yang saat ini menjadi faktor penting dalam pembelajaran online. Pembelajaran dalam jaringan juga akan terlaksana dengan baik jika tersedianya faktor pendukung eksternal fasilitas yaitu handphone, kuota internet maupun bantuan kuota, aplikasi whatsApp berjalan dengan baik sehingga dapat mengikuti informasi, dan jaringan internet stabil. .Pentingnya keberadaan fasilitas dalam kelancaran proses belajar mengajar, seperti laptop, komputer, dan handphone yang memudahkan guru untuk memberikan materi belajar mengajar secara dalam jaringan . 
Faktor pendukung diperlukan upaya mengoptimalkan dan perlunya upaya mengatasi faktor penghambat dalam pembelajaran tematik berbasis sistem dalam jaringan agar tujuan pembelajaran dapat tercapai.

Tabel 2. Upaya Mengoptimalkan Faktor Pendukung dan Mengatasi Faktor Penghambat

\begin{tabular}{|c|c|c|}
\hline \multicolumn{2}{|c|}{ Aspek Pendukung } & Penghambat \\
\hline & $\begin{array}{l}\text { Memberikan motivasi } \\
\text { kepada siswa }\end{array}$ & $\begin{array}{l}\text { Rasa malas } \\
\text { belajar }\end{array}$ \\
\hline $\begin{array}{l}\text { Optimalisasi } \\
\text { faktor } \\
\text { pendukung }\end{array}$ & & $\begin{array}{l}\text { Pendataan bantuan kuota } \\
\text { internet } \\
\text { dari kemendikbud secara } \\
\text { berkala }\end{array}$ \\
\hline $\begin{array}{l}\text { Cara mengatasi } \\
\text { faktor } \\
\text { penghambat }\end{array}$ & $\begin{array}{l}\text { Kerja sama guru dan orang } \\
\text { tua dalam memberikan } \\
\text { motivasi dan perhatian } \\
\text { belajar }\end{array}$ & $\begin{array}{l}\text { Bantuan dari saudara } \\
\text { Adanya hubungan yang } \\
\text { baik antara steckholder } \\
\text { pihak sekolah dan } \\
\text { orangtua }\end{array}$ \\
\hline
\end{tabular}

Tabel 2 menunjukkan upaya mengoptimalkan faktor pendukung internal yaitu guru dan orang tua bekerja sama untuk tetap memberikan perhatian dan motivasi belajar kepada peserta didik. Pemberian hadiah memiliki fungsi untuk penguat respon yang positif. Pemberian motivasi juga dapat mengatasi faktor penghambat internal rasa malas. Motivasi yang diberikan secara materi atau non materi diharapkan peserta didik lebih semangat belajar, aktif mengerjakan tugas dari guru, dan berlomba- lomba untuk mendapatkan nilai terbaik dalam ujian semester. Upaya mengoptimalkan faktor eksternal pendampingan orang tua yaitu pengumpulan tugas peserta didik tepat waktu. Selain itu faktor eksternal fasilitas yaitu bantuan kuota internet kemendikbud dapat dilakukan dengan mendata dan memantau pendistribusian secara berkala. Kemendibud berusaha melakukan penyaluran dan optimalisasi proses verifikasi dan validasi secara maksimal.

Hambatan faktor eksternal dari pendampingan orang tua dapat dilakukan dengan meminta bantuan saudara. Selain itu faktor penghambat eksternal fasilitas dapat diatasi dengan meminta bantuan guru, bantuan antar orang tua dan peserta didik, serta bantuan dari peran masyarakat.

Prinsip pelaksanaan pembelajaran dalam jaringan yaitu memiliki tujuan yang jelas, relevan dengan kebutuhan, meningkatkan mutu pendidikan, efisien dan efektivitas program, pemerataan dan perluasan kesempatan belajar, kemandirian, keterpaduan, dan kesinambungan

Prinsip tersebut terlaksana dalam pembelajaran tematik berbasis sistem dalam jaringan di Kelas II SDN Karangmangu 02 Kecamatan Tarub Kabupaten Tegal. 


\section{SIMPULAN}

Implementasi pembelajaran tematik berbasis sistem dalam jaringan di kelas II SDN Karangmangu 02 Kecamatan Tarub pada tahun 2020 dilaksanakan sesuai Surat Edaran Kemendikbud Nomor 15 Tahun 2020 tentang Pelaksanaan Pendidikan Dalam Masa Darurat Corona Virus Disease (Covid-19) dengan memperhatikan kondisi peserta didik dan pertimbangan orang tua. Pembelajaran tematik berbasis sistem dalam jaringan tetap memperhatikan tahapan pembelajaran yaitu perencanaan, pelaksanaan, dan evaluasi. Pelaksanaan pembelajaran terlaksana dengan baik dengan adanya faktor pendukung internal yaitu minat belajar peserta didik yang dioptimalkan dengan memberikan perhatian dan motivasi belajar. Sedangkan faktor pendukung eksternal yaitu orang tua dapat mendampingi belajar peserta didik dengan maksimal yang dioptimalkan dengan mengumpulkan tugas peserta didik tepat waktu. Faktor pendukung eksternal fasilitas yaitu tersedianya fasilitas gadged, whatsApp dapat berjalan dengan baik sehingga dapat mengikuti informasi, adanya kuota internet atau bantuan kuota belajar, dan jaringan yang stabil. Faktor pendukung tersebut dapat dioptimalkan dengan pendataan bantuan fasilitas kuota internet dari kemendikbud secara berkala. Selain itu ada hambatan yaitu faktor penghambat internal yaitu rasa malas belajar dapat diatasi dengan guru dan orang tua bekerja sama untuk memberikan motivasi belajar dan perhatian seperti memberikan semangat belajar dan memberikan hadiah. Faktor penghambat eksternal yaitu orang tua tidak maksimal dalam memberikan pendampingan karena sibuk bekerja dapat diatasi dengan meminta bantuan saudara. Faktor penghambat eksternal lainnya yaitu tidak tersedianya handphone di rumah, aplikasi whatsApp eror sehingga tertinggal informasi, keterbatasan kuota, dan jaringan internet kurang stabil. Faktor tersebut dapat diatasi dengan bantuan guru, bantuan antar orang tua dan peserta didik, serta bantuan dari peran masyarakat. Penelitian ini masih jauh dari kata sempurna, masih banyak kekurangan dan masukan dari pihak yang terkait terutama dewan Guru dan Kepala Sekolah SDN Karangmangu 02.

\section{DAFTAR PUSTAKA}

A Kurniawan 2020 Pemanfaatan JB Class untuk Mendorong Kemandirian Belajar Siswa dalam Pembelajaran Daring di Masa Pandemi COVID-19 Ideguru J. Karya IIm. Guru 5(1) 1-8

F Jaya 2019 Perencanaan Pembelajaran Medan: Fakultas Ilmu Tarbiyah dan Keguruan UIN

F I S K Wardani 2019 Analisis Kesulitan Guru Dalam Mengembangkan Desain Pembelajaran Tematik Kelas IV Sekolah Dasar Fundam. Pendidik. Dasar 2(2) 64- 68

H A Rigianti 2020 Kendala Pembelajaran Daring Guru Sekolah Dasar di Kabupaten Banjarnegara Elem. Sch. 7(2) 297-302

H Putria, L H Maula, and D A Uswatun 2020 Analisis Proses Pembelajaran Dalam Jaringan (DARING) Masa Pandemi COVID-19 pada Guru Sekolah Dasar J. basicedu 4(4) 861-872

Kemendikbud 2020 Surat Edaran Sekretaris Jenderal No.15 Tahun 2020 Pedoman Pelaksanaan Belajar Dari Rumah Selama Darurat Bencana COVID-19 di Indonesia Sekr. Nas. SPAB (Satuan Pendidik. Aman Bencana), no. 15 1-16

Media Indonesia 2020 Belajar di Masa Pandemi

N Ain and M Kurniawati 2013 Implementasi Kurikulum KTSP: Pembelajaran Tematik di Sekolah Dasar J. Inspirasi Pendidik. 3(2) 316-328

Presiden Republik Indonesia 2018 Undang Undang Nomor 6 tahun 2018 tentang Kekarantinaan Wilayah

Presiden Republik Indonesia 2020 Peraturan Pemerintah Republik Indonesia Nomor 21 Tahun 2020 
S Siyoto and A Sondik 2015 Dasar-Dasar Metodologi Penelitian Yogyakarta: Literasi Media Publishing

Sugiyono 2017 Metodologi Penelitian Pendidikan Bandung: Alfabeta R Ananda 2019 Perencanaan Pembelajaran Medan: Lembaga Peduli Pengembangan Pendidikan Indonesia (LPPPI) 